\title{
Prostate Cancer Risk and ESR1 TA, ESR2 CA Repeat Polymorphisms
}

\section{Citation}

McIntyre, M. H., P. W. Kantoff, M. J. Stampfer, L. A. Mucci, D. Parslow, H. Li, J. M. Gaziano, M. Abe, and J. Ma. 2007. "Prostate Cancer Risk and ESR1 TA, ESR2 CA Repeat

Polymorphisms." Cancer Epidemiology Biomarkers \& Prevention 16 (11): 2233-36. https:// doi.org/10.1158/1055-9965.epi-07-0481.

\section{Permanent link}

http://nrs.harvard.edu/urn-3:HUL.InstRepos:41292894

\section{Terms of Use}

This article was downloaded from Harvard University's DASH repository, WARNING: This file should NOT have been available for downloading from Harvard University's DASH repository.

\section{Share Your Story}

The Harvard community has made this article openly available.

Please share how this access benefits you. Submit a story. 


\title{
Prostate Cancer Risk and ESR1 TA, ESR2 CA Repeat Polymorphisms
}

\author{
Matthew H. McIntyre, ${ }^{1,6}$ Philip W. Kantoff, ${ }^{3}$ Meir J. Stampfer, ${ }^{1,4}$ Lorelei A. Mucci, ${ }^{1,4}$ \\ Diane Parslow, ${ }^{3}$ Haojie Li, ${ }^{1}$ J. Michael Gaziano, ${ }^{2,5}$ Miyako Abe, ${ }^{3}$ and Jing Ma $^{1}$ \\ ${ }^{1}$ Channing Laboratory, Department of Medicine and ${ }^{2}$ Division of Preventive Medicine, Brigham and Women's Hospital and \\ Harvard Medical School, ${ }^{3}$ Dana-Farber Cancer Institute, ${ }^{4}$ Department of Epidemiology, Harvard School of Public Health, \\ ${ }^{5}$ Massachusetts Veterans Epidemiology Research and Information Center, VA Boston Healthcare System, Boston, \\ Massachusetts and ${ }^{6}$ Department of Anthropology, University of Central Florida, Orlando, Florida
}

\begin{abstract}
Background: Experimental evidence has suggested that estrogen receptor $\alpha$ (coded by the gene ESR1) might increase prostate cancer risk, whereas estrogen receptor $\beta$ (coded by the gene ESR2) might reduce prostate cancer risk.

Methods: We investigated the relationship with prostate cancer risk of both a TA repeat polymorphism in the ESR1 5' region, ESR1 (TA) $n$, and with a CA repeat polymorphism in intron 5 of ESR2, ESR2 (CA) ${ }_{n}$, in a case-control study (545 cases and 674 controls) nested in the Physicians' Health Study.
\end{abstract}

Results: Prostate cancer risk was highest for carriers of ESR1 $(\text { TA })_{24}$ and ESR1 (TA) 25 . Replacing one modal ESR1 (TA) 14 allele with one ESR1 (TA) 24 allele yielded an odds ratio of 1.42 (95\% confidence interval, 1.00-2.00; $P=0.05$ ). Replacing one ESR1 (TA) 14 allele with one ESR1 (TA) $)_{25}$ allele yielded an odds ratio of $2.10(95 \%$ confidence interval, 1.15-3.84; $P=0.02)$. ESR2 $(C A)_{n}$ showed no effects on prostate cancer risk.

Conclusions: The ESR1 (TA) $)_{n}$ polymorphism might play a role in prostate cancer risk. (Cancer Epidemiol Biomarkers Prev 2007;16(11):2233-6)

\section{Introduction}

Effects on risk of prostate cancer of endogenous estrogens and other sex steroid hormones remain controversial. Both estrogen receptors (ER) $\alpha$ and $\beta$ (coded by the genes ESR1 and ESR2, respectively) are expressed in human and murine prostate tissue and regulate epithelial growth (1-3). Whereas ER $\alpha$ expression has been proposed to increase prostate cancer risk (3), recent evidence suggests that ER $\beta$ expression might reduce risk by binding with an androstanediol, $5 \alpha$-androstane- $3 \beta, 17 \beta$-diol (4-6). Accounting for different estrogen pathways could help to resolve contradictory findings about the effects of endogenous estrogens and androstanediols on prostate cancer risk.

A thymine-adenine $(\mathrm{TA})_{\mathrm{n}}$ dinucleotide repeat polymorphism in the $5^{\prime}$ promoter region of the ESR1 gene might affect $E R \alpha$ activity. In Caucasian populations, the frequency of repeat lengths exhibits a bimodal distribution peaking sharply at $(\mathrm{TA})_{14}$ followed by very low allele frequency between (TA) $)_{16}$ and (TA) 19 and a shallower peak at $(\mathrm{TA})_{23}$. Most prior epidemiologic research has compared long versus short alleles, defined in various ways (7-13), with some exceptions (14-17).

\footnotetext{
Received 5/27/07; revised 8/16/07; accepted 8/22/07.

Grant support: NIH award CA058684 (M.J. Stampfer) and National Cancer Institute postdoctoral training fellowship CA009001 (M.H. McIntyre).

The costs of publication of this article were defrayed in part by the payment of page charges. This article must therefore be hereby marked advertisement in accordance with 18 U.S.C. Section 1734 solely to indicate this fact.

Requests for reprints: Matthew H. McIntyre, Channing Laboratory, Department of Medicine, Brigham and Women's Hospital and Harvard Medical School,

181 Longwood Avenue, Boston, MA 02115. Phone: 617-549-1627.

E-mail: mmcintyr@mail.ucf.edu

Copyright (C) 2007 American Association for Cancer Research.

doi:10.1158/1055-9965.EPI-07-0481
}

Longer $(\mathrm{TA})_{\mathrm{n}}$ is associated with increased risk of coronary artery disease $(8,10)$, lower concentrations of small low-density lipoprotein particles in women (7), blunted endothelial plasminogen activator release in women (18), and reduced adenosine-stimulated myocardial perfusion in men (9). Longer (TA $)_{n}$ has also been associated with higher osteoarthritis risk (14), reduced bone mineral density and greater history of fractures (11), and reduced risk of endometriosis $(15,16)$, suggesting reduced ER $\alpha$ expression. However, only a small and nonsignificant reduced risk of endometrial cancer has been associated with longer alleles, defined as $(\mathrm{TA})_{\geq 19}$, relative to $(\mathrm{TA})_{<19}$ repeats (12).

A cytosine-adenine $(\mathrm{CA})_{\mathrm{n}}$ dinucleotide repeat polymorphism in intron 5 of the ESR2 gene has been linked to $E R \beta$ expression. Longer $(C A)_{n}$, defined as $(C A)_{\geq 24}$, has been associated with reduced testosterone levels and increased sex hormone binding globulin in women, relative to $(\mathrm{CA})_{<24}$ repeats (13). Longer repeat lengths have also been associated with higher osteoarthritis risk (14), lower bone mineral density in women $(19,20)$, higher blood pressure (21), and less severe menstrual symptoms (22). However, a large study of endometrial cancer risk found no association with long repeat length, defined as $(\mathrm{CA})_{\geq 22}$, relative to $(\mathrm{CA})_{<22}(23)$.

One study has found an association between a polymorphism in codon 10 of ESR1 and prostate cancer risk (24). Another recent study detected an effect of a different ESR1 SNP (rs2234693) on prostate cancer grade at diagnosis, but not total risk of either familial or sporadic prostate cancer (25), and no association with one ER $\beta$ SNP. They also investigated both ESR1 (TA) and ESR2 $(\mathrm{CA})_{\mathrm{n}}$ with risk of sporadic and familial prostate cancer (25). They modeled additive effects of all alleles and found no evidence for an overall effect of 
Table 1. Study participants by level of covariates and case-control status

\begin{tabular}{|c|c|c|}
\hline & $\begin{array}{c}\text { Cases } \\
(n=545)\end{array}$ & $\begin{array}{l}\text { Controls } \\
(n=674)\end{array}$ \\
\hline Age at baseline, ${ }^{*}$ mean (SD) & $61.09(7.35)$ & $61.20(7.64)$ \\
\hline Weight $(\mathrm{kg})$, mean (SD) & $79.22(9.40)$ & $77.77(9.50)$ \\
\hline Height $(\mathrm{cm})$, mean (SD) & $178.76(6.14)$ & $177.95(6.84)$ \\
\hline \multicolumn{3}{|l|}{ Smoking, $n(\%)$} \\
\hline Current smokers & $42(7.71)$ & $57(8.46)$ \\
\hline Former smokers & $251(46.06)$ & $315(46.74)$ \\
\hline \multicolumn{3}{|l|}{ Tumor grade, $n(\%)$} \\
\hline $\begin{array}{l}\text { Gleason } \geq 7 \text { or poorly } \\
\text { differentiated }\end{array}$ & $190(34.86)$ & \\
\hline $\begin{array}{l}\text { Gleason }<7 \text { or well } \\
\text { differentiated }\end{array}$ & $296(54.31)$ & \\
\hline Unknown & $59(10.83)$ & \\
\hline \multicolumn{3}{|l|}{ Stage, $n(\%)$} \\
\hline Died of prostate cancer & 117 (21.47) & \\
\hline Diagnosed with Metastases & $16(2.94)$ & \\
\hline $\begin{array}{l}\text { Whitmore-Jewett stage C or D } \\
\text { at initial diagnosis }\end{array}$ & 86 (15.78) & \\
\hline $\begin{array}{l}\text { Whitmore-Jewett stage A or B } \\
\text { at initial diagnosis }\end{array}$ & 277 (50.83) & \\
\hline Unknown & $49(8.99)$ & \\
\hline
\end{tabular}

*Matching factor.

either polymorphism. We report the results of a study that also investigated the association between prostate cancer risk and ESR1 (TA) n and ESR2 (CA) $)_{n}$ among participants in the Physicians' Health Study.

\section{Materials and Methods}

Participant Selection and Medical Record Review. Prostate cancer cases were identified from participants in the Physicians' Health Study, which began in 1982 as a randomized trial of aspirin and $\beta$-carotene among 22,071 U.S. male physicians (26). Men with a history of myocardial infarction, stroke, transient ischemic attack, unstable angina, cancer (other than nonmelanoma skin cancer), or current renal or liver disease, peptic ulcer, gout, use of platelet-active agents, vitamin $A$, or $\beta$-carotene supplements were excluded from enrollment. Baseline information, including age, smoking history, and race, was collected by self-administered questionnaire, and 93\% classified their race as Caucasian. Before randomization, 14,916 men provided a blood sample.

Prostate cancer diagnoses were initially identified by annual follow-up questionnaires, and all cases were confirmed by review of medical records. We follow participants for occurrence of metastases and death. In this article, we defined advanced stage as WhitmoreJewett stage $C$ or $D$ at diagnosis or having been diagnosed with metastases or having died of prostate cancer during follow-up. We defined high grade as Gleason $\geq 7$ or "poorly differentiated" tumors.

For our nested case-control study, prostate cancer cases were matched with one or two controls by age (within 1 year if younger than 55 or within 5 years if older) and smoking status (past, current, or never). Genetic analyses reported in this article include 545 cases and 674 matched controls from diagnosed 1982 to 1995 and who had also provided blood samples.
Genotyping. Genomic DNA was prepared from frozen blood (QIAamp, Qiagen, Inc.). For both polymorphisms, genomic DNA (50 ng) was amplified using 22.5 pmol of each primer in $25 \mu \mathrm{L}$ PCR buffer B (Invitrogen Corp.) containing $2 \mathrm{mmol} / \mathrm{L} \mathrm{MgCl}_{2}(\mathrm{pH}$ 8.5) plus $1.6 \mathrm{mmol} / \mathrm{L} \mathrm{dNTP}$ and 1 unit of Platinum Taq Polymerase (Invitrogen). The PCR had an initial denaturing temperature at $95^{\circ} \mathrm{C}(2 \mathrm{~min})$ followed by 35 cycles of denaturing $\left(95^{\circ} \mathrm{C} ; 30 \mathrm{~s}\right)$, annealing $\left(60^{\circ} \mathrm{C} ; 30 \mathrm{~s}\right)$, and extension $\left(72^{\circ} \mathrm{C} ; 30 \mathrm{~s}\right)$. A 7 -min extension at $72^{\circ} \mathrm{C}$ followed the final cycle. Mixed with Gene Scan-500 ROX Size Standard (Applied Biosystems), PCR products were applied to a POP-4 capillary array that was linked to an automated fluorescence detection system, ABI PRISM 3100 Gene Analyzer (Applied Biosystems). The primers for the ESR1 (TA) n polymorphism were 5'FAMGTATAAACTATCCAAGATTA-3' and 5'-GCAGAATCAAATATCCAGATG-3' and those for the ESR2 (CA)n polymorphism were 5'HEX-GGTAAACCATGGTCTGTACC-3' and 5'-AACAAAATGTTGAATGAGTGGG-3'. Using analysis software, GeneScan Analysis 2.1 (Applied Biosystems), ESR1 (TA $)_{n}$ was calculated as (fragment length $-144 \mathrm{bp}$ ) / 2 and ESR2 (CA) $)_{\mathrm{n}}$ as (fragment length $-117 \mathrm{bp}$ ) / 2. The genetic laboratory was blind to the case-control status of samples.

Statistical Methods. Each repeat length allele was scored as 0,1 , or $2(27,28)$ depending on the number of alleles carried by the participant and entered into an unconditional logistic regression following Cunningham et al. (25). Regression models were adjusted for matching factors: age, smoking, and follow-up time. We also conducted further analyses stratifying cases by stage and grade at diagnosis. We report the likelihood ratio test of each full additive model with a model containing only covariates. Given the large number of alleles for each of these polymorphisms, 22 for ESR1 $(\mathrm{TA})_{\mathrm{n}}$ and 14 for ESR2 (CA) $)_{\mathrm{n}}$, the power of these global tests is low. Therefore, we also discuss contrasts with modal alleles (Table 1).

\section{Results}

Polymorphisms showed statistically significant global effects neither on total prostate cancer risk [ESR1 (TA)

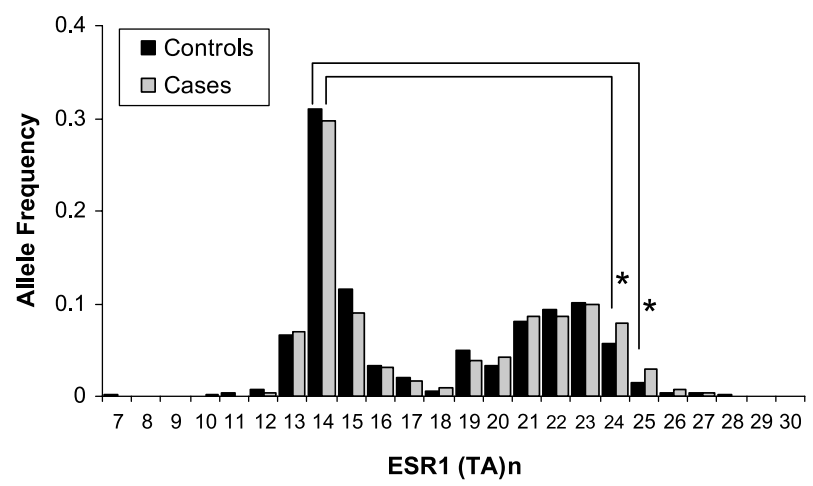

Figure 1. ESR1 $(\mathrm{TA})_{\mathrm{n}}$ distribution by case/control status. Global $P=0.08$. Contrasts with ESR1 (TA $)_{14}$ indicated with a “*” $P<0.05$. 


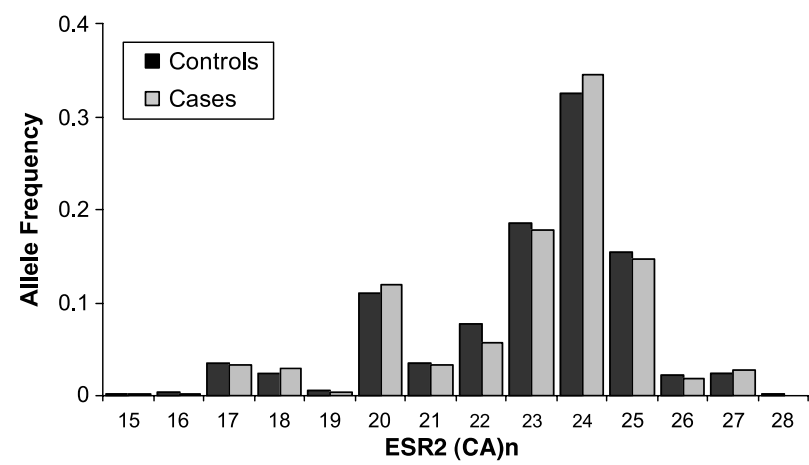

Figure 2. ESR2 $(\mathrm{CA})_{\mathrm{n}}$ distribution by case/control status. Global $P=0.69$.

global $P=0.08$, ESR2 $(\mathrm{CA})_{\mathrm{n}}$ global $\left.P=0.69\right]$ nor on risk of high-grade prostate cancer [ESR1 (TA) global $P=0.31$, ESR2 $(\mathrm{CA})_{\mathrm{n}}$ global $P=0.38$ ] nor on risk of advanced prostate cancer [ESR1 (TA) n global $P=0.55$, ESR2 $(\mathrm{CA})_{\mathrm{n}}$ global $\left.P=0.40\right]$. However, two alleles of ESR1 $(\mathrm{TA})_{\mathrm{n}}(n=24$ and $n=25)$ were disproportionately carried by cases, relative to modal ESR1 (TA) 14 repeats. The effects of these alleles can be expressed as relative odds associated with replacing one ESR1 $(\mathrm{TA})_{14}$ allele with one ESR1 (TA) 24 allele (odds ratio, $1.42 ; 95 \%$ confidence interval, $1.00-2.00 ; P=0.05)$ or replacing one ESR1 $(\mathrm{TA})_{14}$ allele with one ESR1 $(\mathrm{TA})_{25}$ allele (odds ratio, 2.10; 95\% confidence interval, 1.153.84; $P=0.02$; Figs. 1 and 2).

\section{Discussion}

We did not detect significant global effects of either ESR1 $(\mathrm{TA})_{\mathrm{n}}$ or ESR2 $(\mathrm{CA})_{\mathrm{n}}$ on risk of total, high-grade, or advanced prostate cancer. However, two alleles of ESR1 $(\mathrm{TA})_{\mathrm{n}}, n=24$ and $n=25$, were disproportionately carried by cases.

Given that significant overall associations of these polymorphisms with prostate cancer risk or phenotype were not observed in prior large study (25), it is possible that we observed elevation in prostate cancer risk for carriers of ESR1 $(\mathrm{TA})_{24}$ and ESR1 $(\mathrm{TA})_{25}$ by chance. Nevertheless, the global tests used both in this study and by Cunningham et al. (25) are similarly underpowered for effects of moderate size. It is therefore worth considering whether our more exploratory findings of effects of individual alleles, in conjunction with other results suggesting reduced estrogenicity of longer repeats, imply a potential role for ER $\alpha$ in prostate cancer carcinogenesis.

Although experimental research shows that ER $\alpha$ expression promotes squamous cell metaplasia (3), human prostate cancer has been associated with a polymorphism at codon 10 of ESR1 (24) that seems to reduce $\mathrm{ER} \alpha$ activity, given its opposite association with endometrial cancer (29). Our results also suggest that lower ER $\alpha$ expression increases prostate cancer risk. Substantial prior evidence shows that long repeat length of ESR1 $(\mathrm{TA})_{\mathrm{n}}$ is associated with reduced $\mathrm{ER} \alpha$ expression, with the notable exception that no association was found with endometrial cancer.
In summary, we found some preliminary evidence linking a TA repeat polymorphism in the $5^{\prime}$ region of ESR1 with both prostate cancer and hormone levels. Our results suggest that $\mathrm{ER} \alpha$ activity may reduce prostate cancer risk.

\section{Acknowledgments}

We thank the thousands of men who participate in the Physicians' Health Study and Monica McGrath for advice on data analysis.

\section{References}

1. Cunha GR, Ricke W, Thomson A, et al. Hormonal, cellular, and molecular regulation of normal and neoplastic prostatic development. J Steroid Biochem Mol Biol 2004;92:221-36.

2. King KJ, Nicholson HD, Assinder SJ. Effect of increasing ratio of estrogen: androgen on proliferation of normal human prostate stromal and epithelial cells, and the malignant cell line LNCaP. Prostate 2006;66:105-14.

3. Risbridger $G$, Wang $H$, Young $P$, et al. Evidence that epithelial and mesenchymal estrogen receptor- $\alpha$ mediates effects of estrogen on prostatic epithelium. Dev Biol 2001;229:432-42.

4. Guenrini V, Sau D, Scaccianoce $E$, et al. The androgen derivative $5 \alpha$-androstane- $3 \beta, 17 \beta$-diol inhibits prostate cancer cell migration through activation of the estrogen receptor $\beta$ subtype. Cancer Res 2005;65:5445-53.

5. Weihua $Z$, Lathe $R$, Warner M, Gustafsson J-Å. An endocrine pathway in the prostate, ER $\beta, A R, 5 \alpha$ androstane $3 \beta, 17 \beta$ diol, and CYP7B1, regulates prostate growth. Proc Natl Acad Sci U S A 2002; 99:13589-94

6. Weihua Z, Mäkelä S, Andersson LC, et al. A role for estrogen receptor $\beta$ in the regulation of growth of the ventral prostate. Proc Natl Acad Sci U S A 2001;98:6330-5.

7. Demissie S, Cupples LA, Shearman AM, et al. Estrogen receptor- $\alpha$ variants are associated with lipoprotein size, distribution, and particle levels in women: the Framingham Heart Study. Atherosclerosis 2006;185:210-8.

8. Kunnas TA, Laippala P, Penttilä A, Lehtimäki T, Karhunen PJ. Association of polymorphism of human $\alpha$ oestrogen receptor with coronary artery disease in men: a necropsy study. BMJ 2000;321:273-4

9. Kunnas TA, Lehtimäki T, Karhunen PJ, et al. Estrogen receptor genotype modulates myocardial perfusion in young men. J Mol Med 2004;82:821-5

10. Lu H, Higashikata $\mathrm{T}$, Inazu A, et al. Association of estrogen receptor$\alpha$ gene polymorphisms with coronary artery disease in patients with familial hypercholesterolemia. Arterioscler Thromb Vasc Biol 2002; 22:821-7.

11. van Meurs JBJ, Schuit SCE, Weel AEAM, et al. Association of 5 estrogen receptor $\alpha$ gene polymorphisms with bone mineral density, vertebral bone area and fracture risk. Hum Mol Genet 2003;12: $1745-54$.

12. Weiderpass E, Persson $I$, Melhus H, Wedrén S, Kindmark A, Baron JA. Estrogen receptor $\alpha$ gene polymorphism and endometrial cancer risk. Carcinogenesis 2000;21:623-7.

13. Westberg L, Baghaei F, Rosmond R, et al. Polymorphisms of the androgen receptor gene and the estrogen receptor $\beta$ gene are associated with androgen levels in women. J Clin Endocrinol Metab 2001;86:2562-8

14. Fyliti P, Giannatou E, Papanikolaou V, et al. Association of repeat polymorphisms in the estrogen receptors $\alpha, \beta$, and androgen receptor genes with knee osteoarthritis. Clin Genet 2005;68:268-77.

15. Georgiou I, Syrrou M, Bouba I, et al. Association of estrogen receptor gene polymorphisms with endometriosis. Fertil Steril 1999;72:164-6.

16. Hsieh Y-Y, Chang C-C, Tsai F-J, Lin C-C, Tsai C-H. Estrogen receptor $\alpha$ dinucleotide repeat and cytochrome $\mathrm{P} 450 \mathrm{c} 17 \alpha$ gene polymorphisms are associated with susceptibility to endometriosis. Fertil Steril 2005;83:567-72.

17. Rokach A, Pollack A, Rosen L, et al. Estrogen receptor $\alpha$ gene polymorphisms are associated with the angiographic extent of coronary artery disease. J Clin Endocrinol Metab 2005;90:6556-60.

18. Hoetzer GL, Irmiger HM, Stauffer BL, DeSouza CA. Estrogen receptor- $\alpha$ thymidine and adenine repeat polymorphism and endothelial fibrinolytic regulation in postmenopausal women. Am J Obstet Gynecol 2005;193:366-70.

19. Ogawa $S$, Hosoi $T$, Shiraki $M$, et al. Association of estrogen receptor $\beta$ gene polymorphism with bone mineral density. Biochem Biophys Res Commun 2000;269:537-41.

20. Scariano JK, Simplicio SG, Montoya GD, Garry PJ, Baumgartner RN. 
Estrogen receptor $\beta$ dinucleotide (CA) repeat polymorphism is significantly associated with bone mineral density in postmenopausal women. Calcif Tissue Int 2004;74:501-8.

21. Ogawa S, Emi M, Shiraki M, Hosoi T, Ouchi Y, Inoue S. Association of estrogen receptor $\beta$ (ESR2) gene polymorphism with blood pressure. J Hum Genet 2000;45:327-30.

22. Takeo C, Negishi E, Nakajima A, et al. Association of cytosineadenine repeat polymorphism of the estrogen receptor- $\beta$ gene with menopausal symptoms. Gend Med 2005;2:96-105.

23. Setiawan VW, Hankinson SE, Colditz GA, Hunter DJ, De Vivo I. Estrogen receptor $\beta$ (ESR2) polymorphisms and endometrial cancer (United States). Cancer Causes Control 2004;15:627-33.

24. Tanaka Y, Sasaki M, Kaneuchi M, Shiina H, Igawa M, Dahiya R. Polymorphisms of estrogen receptor $\alpha$ in prostate cancer. Mol Carcinog 2003;37:202-8.
25. Cunningham JM, Hebbring SJ, McDonnell SK, et al. Evaluation of genetic variation in the androgen and estrogen metabolic pathways as risk factors for sporadic familial prostate cancer. Cancer Epidemiol Biomarkers Prev 2007;16:969-78.

26. Steering Committee of the Physicians' Health Study Research Group. Final report on the aspirin component of the ongoing Physicians' Health Study. N Engl J Med 1989;321:129-35.

27. Schaid DJ. Evaluating associations of haplotypes with traits. Genet Epidemiol 2004;27:348-64.

28. Schaid DJ, Rowland CM, Tines DE, Jacobson RM, Poland GA. Score tests for association between traits and haplotypes when linkage phase is ambiguous. Am J Hum Genet 2002;70:425-34.

29. Sasaki M, Tanaka Y, Kaneuchi M, Sakuragi N, Dahiya R. Polymorphisms of estrogen receptor $\alpha$ gene in endometrial cancer. Biochem Biophys Res Commun 2002;297:558-64. 


\section{Cancer Epidemiology, \\ Biomarkers \& Prevention}

\section{Prostate Cancer Risk and ESR1 TA, ESR2 CA Repeat Polymorphisms}

Matthew H. McIntyre, Philip W. Kantoff, Meir J. Stampfer, et al.

Cancer Epidemiol Biomarkers Prev 2007;16:2233-2236.

Updated version Access the most recent version of this article at:

http://cebp.aacrjournals.org/content/16/11/2233

Cited articles This article cites 29 articles, 5 of which you can access for free at:

http://cebp.aacrjournals.org/content/16/11/2233.full\#ref-list-1

Citing articles This article has been cited by 2 HighWire-hosted articles. Access the articles at:

http://cebp.aacrjournals.org/content/16/11/2233.full\#related-urls

E-mail alerts Sign up to receive free email-alerts related to this article or journal.

Reprints and To order reprints of this article or to subscribe to the journal, contact the AACR Publications

Subscriptions Department at pubs@aacr.org.

Permissions To request permission to re-use all or part of this article, use this link http://cebp.aacrjournals.org/content/16/11/2233.

Click on "Request Permissions" which will take you to the Copyright Clearance Center's (CCC)

Rightslink site. 